\title{
METHODS OF ASSESSING THE EFFICIENCY OF INTERNET MARKETING COMMUNICATIONS
}

\author{
Valentyn Halunko ${ }^{1}$, Kseniia Kurkova ${ }^{2}$, Vitalii Oksin ${ }^{3}$
}

\begin{abstract}
The purpose of the study is to systematize the methodological foundations for evaluating the effectiveness of marketing communications on the Internet. In the literature, there are often limited definitions of interactivity, which do not reveal the essence and do not allow fully realizing the marketing opportunities associated with its phenomena. Today, interactive video, gaming technologies, which are increasingly used in the creation of advertising and communication materials, provide unprecedented opportunities for users to create and flexibly change their own scenarios for the development of events, to guide the history of the video and its heroes, which, among other things, makes it possible to make the presentation object not only goods or services but also the practice of behaviour in different situations of their purchase and consumption. In Internet marketing communications, preconditions for estimating the time budget, general stay in the network, implementation of specific behavioural scenarios of the full-fledged functioning of the user as a representative of the target audience, including through various devices and due to multimedia character, are formed. Optimization of Internet communications of enterprises is carried out on the basis of cyclic interactive communication and timely adjustments of parameters of the received traffic from automated services such as Google analytics, Yandex Metrica, CoMagic, and others. An audience behaviour analysis becomes possible by the use of cookie data. This fragment of data stored on Internet users' computers reveals the broad opportunities for enterprises to target their advertising, identifying the target audience, for example, by geographic location of users, tracking their interests, counting impressions and passing through banners. Due to the high level of inherent interactivity, simplification of activity realization, and its coordination in a virtual environment, with real results, the development of marketing communications on the Internet contributes to the transition from the integrated application of specialized tools and technologies to their genuine integration. These new opportunities, subject to their implementation, will update one more aspect - the achievement of the effectiveness of Internet communications in marketing. Attempts and methodical options for the formation of a holistic set of marketing communications, with their declared effectiveness, have become widespread. The author proposes a more adaptive system for evaluating the effectiveness of marketing communications, where a balanced system of indicators and stages of work are complemented by the classical algorithms that create the necessary preconditions for preventing or neutralizing the identified problems in the organization of Internet marketing communications. The effectiveness of the CPM model depends entirely on the derivative results of user behaviour (review of site materials, ordering and purchasing goods). Therefore, depending on the goals of the campaign, that is, expanding the target audience or promoting sales, the result may be more predictable. The success of online platforms is based on the consistent development of activities, which is harmonized by three benchmarks: differentiation, effectiveness, efficiency. If earlier, marketing monitoring of the audience and behaviour of Internet users was mainly based on the features of its persons or contingents, and the information context, today it needs to be integrated (contextual targeting, retargeting, and other tools).
\end{abstract}

Key words: Internet marketing communications, interactivity, marketing activities, media market, media budget, CPM models, audience selection algorithms, economic efficiency.

JEL Classification: M31, L86, D83, G14

\footnotetext{
Corresponding author:

${ }^{1}$ Research Institute of Public Law, Ukraine.

E-mail: halunko@i.ua

${ }^{2}$ Research Institute of Public Law, Ukraine.

E-mail: kurkovaksena@ukr.net

${ }^{3}$ Research Institute of Public Law, Ukraine.

E-mail: 6222410@ukr.net
} 


\section{Introduction}

The progress of civilization gave rise to and resulted in the intensive development of the Internet environment - a global information hypermedia system based on special technological solutions and appropriate infrastructure. By responding to the latest community demands for the organization of communications and access to the knowledge and experience of humanity, the Internet is simultaneously an environment for cooperation and communication, a means of worldwide broadcasting and dissemination of information, with the necessary complementarity and synergy of all branches of knowledge and life aspects of society. The Internet serves as a convenient and economically attractive virtual business area with a powerful arsenal of fundamentally new tools to improve profitability. The urgency of the work is to study both the concept and classification of Internet communications, as well as to analyse the possibility of its practical use.

Globalization, informatisation, and virtualization at the end of the XX century became the key themesvectors of the influential paradigm of the sciences of man and society, changed the direction in understanding the laws of evolution.

Informatisation and virtualization substantially change the nature and laws of market development, industrialization and technological progress, the development of network flexible forms of intercultural and international engagement of all elements of socioeconomic systems, deny the organizational dominant of national and material, limiting transaction costs, speed, and spatial range in the execution of operations.

The issues of Internet marketing development are considered in the scientific works of such scholars as P. Braslavskyi, S. Harkavenko, L. Hlinenko, T. Zatonatska, S. Illiashenko, I. Kozak, M. Lebedenko, I. Lytovchenko, M. Makarov, O. Muzyka, V. Pylypchuk, V. Pleskach, T. Prymak, I. Reshetnikova. Founders of studies on Internet marketing development were the following scholars: J. Beaumont, E. Awad, G. Milne, R. Wilson, W. Hanson. The works of these authors cover the principles and foundations of marketing in the global network, as in a special environment for the promotion of goods and services in the market, modern approaches to managing the marketing complex, the specific application of its individual tools.

It should be noted that in existing scientific papers, insufficient attention is paid to the issues of assessing the economic efficiency of Internet marketing, its methodological algorithms and techniques, as well as a new systematization of classification approaches, which take into account the interpenetration of previously isolated elements.

The purpose of the study is to systematize the methodological foundations for assessing the effectiveness of marketing communications on the Internet.

\section{The methodology of research}

The development of communications, their means, and technologies has serious and large-scale sociopsychological, cultural, and economic consequences for the entire society, including for marketing. H. McLuhan defines the leading role of communication technologies as a decisive factor in the process of formation of socio-economic systems: "...the personal and social consequences of any means of communication, that is, any our extension outward, come from a new scale brought about by each such extension or new technology in our affairs" (McLuhan, 2006). After all, any extensions of channels and communication devices, time and functionality of the person's stay in the online mode is connected and causes changes in the limits of his/her consciousness and the horizons of perception of the prospect.

In the literature, there are often limited definitions of interactivity that do not reveal the essence and do not allow fully realizing the marketing opportunities associated with its phenomena (Andropova, 2009). In particular, "interactivity is the principle of organizing a system, in which the goal is achieved through an information exchange among elements of this system" (Bozhkova, 2013). Leaving aside the nature of the intended interaction, the researchers create the preconditions for errors in classifications, methodological developments, and the evaluation of the effectiveness of communications.

Today, interactive video, gaming technologies, which are increasingly used in the creation of advertising and communication materials, provide unprecedented opportunities for users to create and flexibly change their own scenarios for the development of events, to guide the history of the video and its heroes, which, among other things, makes it possible to make the presentation object not only goods or services but also the practice of behaviour in different situations of their purchase and consumption.

Accordingly, among advertisers and representatives of different target audiences, commercials are gaining in popularity that not only and not so much provide (represent) information in graphics, video or other format as they interact with the user, turning it from observer to event participant, fully integrate processes of active presentation of proposals and persuasion in making purchasing decisions. Such technologies and practices provide a high level of consumer engagement in communication and sales processes, high quality and performance of contact with the audience (Gayeva, 2015).

Thus, we will define interactive marketing communications as a mutually active informational interaction of market participants that are multilevelly connected in real time by content and contexts, in order to increase the efficiency of exchanges and meet their needs. 
Table 1

Technologies and means of interactivity of communications

\begin{tabular}{|l|l|}
\hline \multicolumn{1}{|c|}{ Name } & \multicolumn{1}{|c|}{ Description } \\
\hline "Live" projections & $\begin{array}{l}\text { Software and hardware complexes and visualization tools projecting the image on any surface } \\
\text { with a flexible active image or video change }\end{array}$ \\
\hline $\begin{array}{l}\text { Touch screen monitors (displays) } \\
\text { and surfaces (display windows etc.) }\end{array}$ & $\begin{array}{l}\text { Coordinate devices that allow you to implement a flexible interface for accessing information } \\
\text { or buying products and services that are activating and sensitive to the user touch }\end{array}$ \\
\hline Image interaction tools (ThingLink) & $\begin{array}{l}\text { Possibility to designate any object of a website or message, click on which expands windows } \\
\text { with the content of a certain subject }\end{array}$ \\
\hline 3D (4D) holograms and displays & $\begin{array}{l}\text { Multidimensional objects and spaces that make it possible to thoroughly and comprehensively view } \\
\text { the desired object or provide a full-fledged presence effect. }\end{array}$ \\
\hline
\end{tabular}

In our view, interactivity in Internet marketing communications should be considered at three hierarchical levels:

I. Interactivity, where the user of information becomes its active generator.

II. Socialization of communication projects, when the subject of discussion becomes the basis of a large-scale social movement.

III. Interpenetration of global social networks, Internet communities, and similar associations, collective actors (of communication, procurement, etc.).

InInternetmarketing communications, the preconditions for estimating the budget of time, general stay in the network, implementation of specific behavioural scenarios of the full functioning of the user as a representative of the target audience, including through various devices and thanks to multimedia, are formed (Nikiforova, 2017).

Internet marketing communications must be fully integrated into the cycle of interactive and renewable interaction with consumers, which results guarantee enterprises profitability and business development.

Optimization of Internet communications of enterprises is carried out on the basis of cyclic interactive communication and timely adjustments of parameters of received traffic from automated services such as Google analytics, Yandex Metrica, CoMagic and others (Orap, 2016, Setevaya ekonomika). An audience behaviour analysis is made possible by the use of cookie data. This small piece of data stored on Internet users' computers reveals a wide range of opportunities for businesses to target their ads, defining a target audience, for example, by geographic location of users, tracking their interests, counting impressions and passing through banners.

Due to the high level of inherent interactivity, simplification of implementation of activities and their coordination in the virtual environment, but with real results, the development of marketing communications on the Internet contributes to the transition from the integrated application of specialized tools and technologies to their genuine integration. These new opportunities, subject to their implementation, update one more facet of the already outlined problem - the achievement of the effectiveness of Internet communications in marketing.

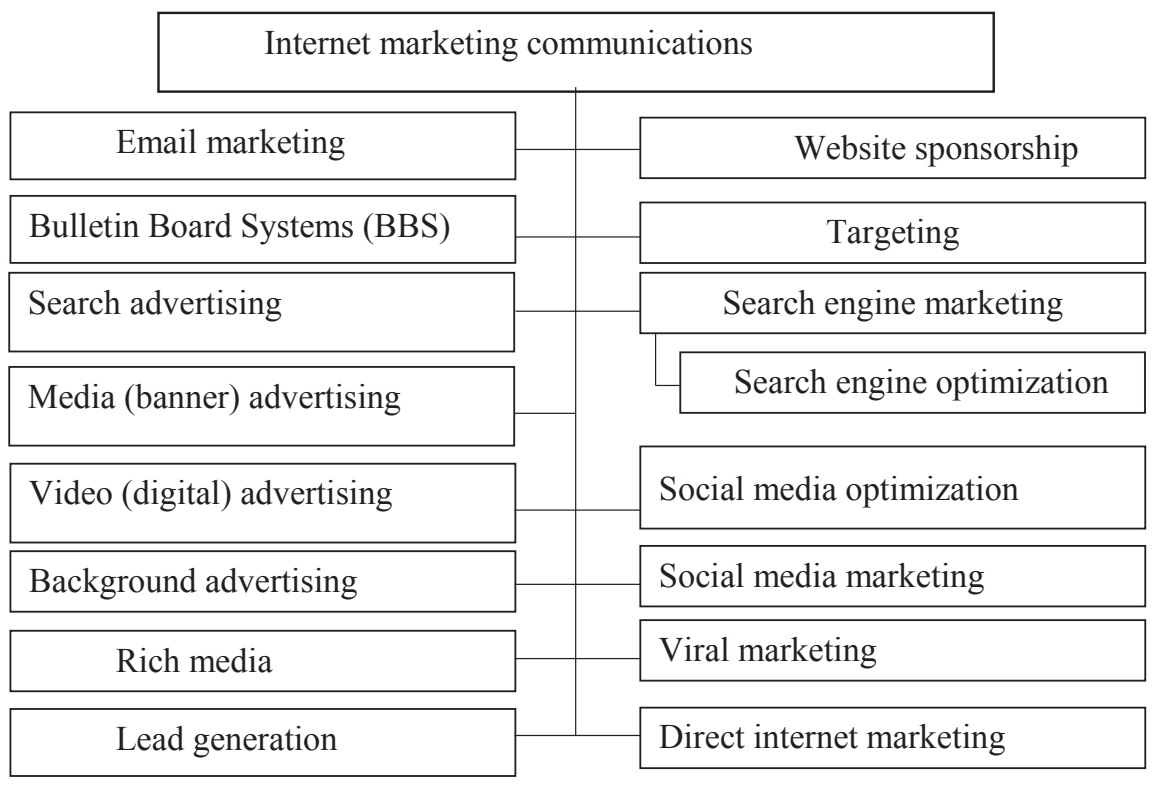

Figure 1. The system of marketing communications on the Internet 


\section{Results and discussion}

The objective market forces and innovation in the field of technology contribute to the modern development of the Internet, all its components, the creation of new forms of value for the market. According to the research company "Pingdom", the global audience of Internet users in the period of 1993-2017 has increased to more than half of the world's population (Figure 2), and the quantitative indicators of the progress of technological capabilities and infrastructure in their dynamics are fully consistent with Moore's law (Zakon Mura), doubling every 5 years.

In January 2018, the number of Internet users in the world reached 4,021 billion people (the entire population of the planet is 7.6 billion). The social networking audience in 2018 amounts to 3.196 billion people, that is, by $+13 \%$ more than in 2017 . And $90 \%$ of users access it through mobile devices, and 3,722 billion people use mobile Internet access technologies. In 2018 , mobile phones are used by 5.135 billion people $4 \%$ more than in 2017 . The most dynamic development is observed in Africa, the Middle East, and Asia. According to published data from international research companies, the number of Internet users in the middle of 2017 amounted to only 3.04 billion people (Obzory rynkov, 2018).

The Internet is unevenly distributed throughout the world. Top 10 countries by a number of Internet users: China - 772 million, India - 350 million, USA 277 million, Japan - 110 million, Brazil - 110 million, Russia - 87 million, Germany - 72 million, Indonesia 71 million, Nigeria - 70 million, Mexico - 59 million.

Almost 1 million people first started using social networks every day in the last year. More and more senior people are joining social networks. Only on Facebook, the number of users aged 65 and older has increased by almost $20 \%$ over the past year. The number of teenagers aged 13 to 17 who use Facebook has also increased, but only 5\% since January 2017.

An average user spends about 6 hours a day on the Internet. The leaders are Thai residents who spend 9 hours and 38 minutes online. The largest amount of time in social networks, for the third year running, is spent by Filipinos - an average of about 6 hours a day.

Global spending on e-commerce in 2017 reached almost $\$ 1.5$ trillion, only on consumer goods. Adding costs to other categories, such as online, tickets, tours purchase, digital content, and mobile apps, then the total world e-commerce price will be closer to $\$ 2$ trillion. UK residents are more likely to make online purchases, with annual spending exceeding $\$ 2000$ per user.

Against the background of the growth of the Internet audience, the natural and predictable is the increase in the capacity and progress of the market and individual segments of Internet marketing communications.

However, the trends in the media and communications market in Ukraine are not unambiguous. The sensitivity of individual users and corporate sector of the economy to fluctuations in the state of affairs is determined by different factors. Requests for information exchange and use of network infrastructure remain high and have stable and active growth for all categories. Marketing activities of enterprises directly depend on investment expectations, business climate conditions. Accordingly, advertising budgets that Ukrainian advertisers allocated for advertising and promoting it on the Internet, as well as using other media channels, increased up to 2014. Ukrainian Advertising Coalition (VRK) has

$4,000,000,000$

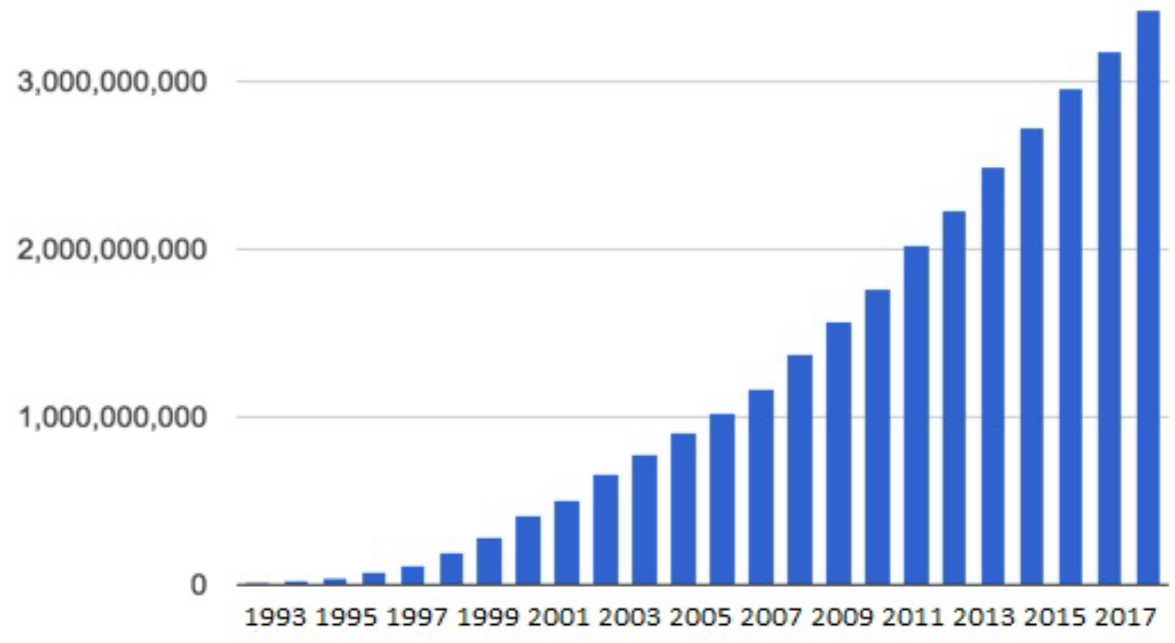

Figure 2. Graf of Internet users in the world from 1993 to 2017

Source: developed on the basis of (Obzory rynkov, 2018) 
established that the volume of the Ukrainian market in 2012 amounted to 13.6 billion UAH, in 2013 14.6 billion UAH, in the crisis 2014 for the country, the Ukrainian advertising and communications market lost almost a quarter of the national currency budgets, the total volume of which amounted to 11.3 billion UAH (Internet World Stats, 2018).

The volume of income from the creation and placement of advertising in Ukraine in 2014 amounted to 9065 million UAH and has grown to 10003 million $\mathrm{UAH}$ in 2017. The main platform for video advertising, which is the most popular and cost-effective in operation, is YouTube, whose audience in Ukraine already reaches 14 million unique visitors per month. Accordingly, the average cost of advertising on it is also high - about 4-5 dollars per thousand impressions, with the expected range of fluctuations depending on the type of commercials, its duration, the target audience, and the possibility to be ignored by the user. Instagram provokes competition to YouTube as an advertising platform.

Experts note the high potential of efficiency and growth of Internet communications in the development of services in the field of communications, managing the reputation of companies in social networks, the use of online gaming technologies (Industriya kompyuternykh igr obgonyayet kinoindustriyu). Analysis of the results of monitoring researches on the distribution of advertising budgets testifies the validity of the conclusions about the need to streamline and improve the classification approaches for structuring the complex of Internet communications (Orap, 2016; Nikiforova, 2017).

On the one hand, there are contradictions and inconsistencies in evaluations of various experts, for example, specialists from the Ukrainian Advertising Coalition and StarLight Sales and others (Kashin, 2014). On the other hand, important directions and types of communications are delayed or indirectly displayed. At the end of 2016, there was a change in the distribution in the structures of evaluation of the advertising and communications market. Its main goal was precisely the harmonization of terms and concepts in accordance with those generally accepted in the European and world advertising markets. It is important

Table 2

The volume of the media advertising market in Ukraine (2014-2017, billion UAH)

\begin{tabular}{|l|c|c|c|c|}
\hline & 2014 billion UAH & 2016 billion UAH & 2017 billion UAH & $\begin{array}{c}\text { Relative deviation } \\
2017 / 2016 \mathrm{~T}_{\mathrm{p}}(\%)\end{array}$ \\
\hline TV advertising & 3930 & 3986 & 4606 & 115,5 \\
\hline Direct advertising & 3555 & 3755 & 4088 & 108,9 \\
\hline TV sponsorship & 375 & 431 & 518 & 120,2 \\
\hline Press advertising & 1670 & 1320 & 1045 & 109,5 \\
\hline OOH advertising & 1030 & 952 & 903 & 109,9 \\
\hline $\begin{array}{l}\text { Billboard outdoor } \\
\text { advertising }\end{array}$ & 875 & 821 & 69 & 107,8 \\
\hline Transit advertising & 70 & 64 & 333 & 109,5 \\
\hline Radio advertising & 290 & 304 & 26 & 108,3 \\
\hline Cinema advertising & 30 & 24 & 2745 & 116,6 \\
\hline Online advertising & 2115 & 8941 & 10003 & 111,9 \\
\hline \multicolumn{1}{|c|}{ Total media market } & 9065 & & & \\
\hline
\end{tabular}

Table 3

Distribution of advertising budgets of the Internet sector by sectors of the economy in 2014-2016, \%

\begin{tabular}{|l|c|c|c|}
\hline \multirow{2}{*}{ Category } & 2014 & 2016 & \multirow{2}{*}{$\begin{array}{c}\text { Percentage of change } \\
\text { in budget volume, } 2016 / 2014\end{array}$} \\
\cline { 2 - 3 } & \multicolumn{2}{|c|}{ The volume of advertising budgets, $\%$} & $-7 \%$ \\
\hline Food & 13 & 12,1 & $-2 \%$ \\
\hline Electronicle & 12,3 & 12 & $-5 \%$ \\
\hline Hygiene, household chemicals & 11,8 & 11,2 & $-24 \%$ \\
\hline Telecommunications & 11 & 8,4 & $-22 \%$ \\
\hline Finance & 10,7 & 8,3 & $-5 \%$ \\
\hline Pharmacy & 7,9 & 7,5 & $85 \%$ \\
\hline Spirits & 3,9 & 7,2 & $30 \%$ \\
\hline Retail & 4,3 & 5,6 & $-40 \%$ \\
\hline Online stores & 8,1 & 4,9 & $246 \%$ \\
\hline Baby stuff & 1,3 & 4,5 & $-17 \%$ \\
\hline Entertainment & 4,1 & 3,4 & $17 \%$ \\
\hline Other & 2,9 & 3,4 & $36 \%$ \\
\hline
\end{tabular}


that Internet advertising received an international classification that is as close as possible to the definitions of Interactive Advertising Bureau (IAB) (Ofitsiynyy sayt Ukrayinskoyi asotsiatsiyi Internet-reklamy, 2018).

When choosing media, companies take into account both the volume of media consumption and the cost of reaching their audience by each channel. Due to the high level of coverage, the TV has the lowest cost per 1000 contacts (CPT) - $15 \mathrm{UAH}$. In the second place - banner advertising on the Internet - $40 \mathrm{UAH}$. The most expensive kind of media are cinemas, the cost of reaching 1000 contacts is 949.2 UAH. That is why television retains its traditional position and leads with coverage of almost $95 \%$. In turn, the use of such media as the press and radio becomes smaller every year, their share decreased by $20 \%$ for the period of 2008-2016.

It is important to note the differences in the integration of offline marketing, which is aimed at the logic (sequence) of advertising messages in the context of enterprise strategy, and online, based on a permanent and personalized interaction with the client. The latter, among other things, exacerbates the issue of effective cross-communications. The more differentiated media become, the more important it is to take into account the peculiarities and variability of their requirements in joining marketing efforts for the effectiveness of maintaining contact with the audience, as well as the full implementation of the communication concept based on original, creative solutions (Petrovskiy, 2012).

Attempts and methodical options for the formation of a holistic set of marketing communications with their declared effectiveness have become widely distributed in professional literature and practice. However, even with their foreseen separation of online tools into a separate group, they are not lacking in contradictions, do not have a single effective systematization.

A successful combination of classical and new approaches is the concept of a modern interpretation of the theory of integrated marketing communications -
TTL (trough the line), which complex is formed by the unification of elements of ATL (above the line) and BTL (below the line). Paid and one-sided reporting of information to consumers by the use of ATL tools (advertising in the press, on radio and television, in cinema, outdoor advertising) can only be conditionally considered uncharacteristic for BTL (sales promotion, direct marketing, public relations, participation in exhibitions, online advertising) (Berezin, 2014).

The proactive elements used to provide interactivity (games, education, discussions, virtual demonstrations and excursions, etc.) are a guarantee of efficiency and must be combined with all the tools of the marketing communications package that is possible in the Internet environment. They cannot be classified in one of the classification groups: BTL or TTL (Kubka, 2017).

It is in this direction, which is often identified with BTL or TTL activities, that about $70 \%$ of the total budget of marketing communications is invested in the late XX and early XXI centuries.

Contradictions that arise as a result of isolation in the implementation of operations and works provided by communication technologies, violations of the integrity of communications do not allow fully implementing marketing strategies in interaction with consumers, ensuring their high efficiency.

In particular, the content of messages, content of websites are often not harmonized with the image of the company, its brands; the information content does not meet the principles of necessity and adequacy, visibility and interactivity of the presentation; requests not of the target audience but of search robots are satisfied; means of visualization, principles and standards of corporate culture change the meaning and perception of marketing information; there is a conflict of goals and objectives for the promotion of goods and services (Hendrik Pol, 2015).

The author proposes a more adaptive assessment system, where a balanced system of indicators and

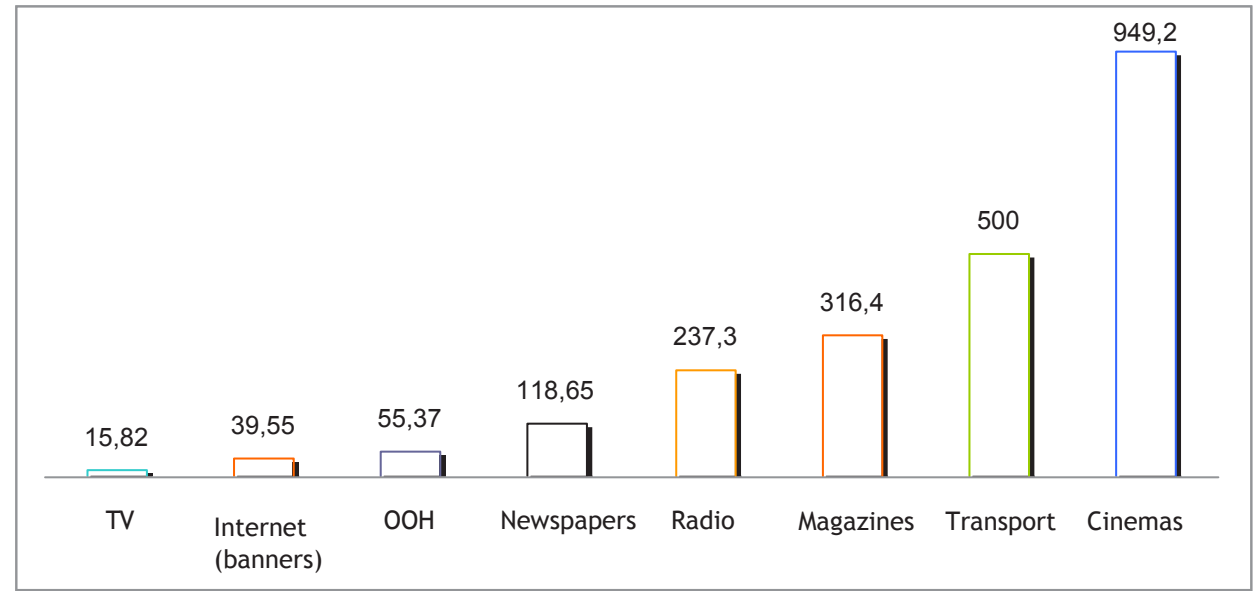

Figure 3. The effectiveness of various media by the cost per thousand (CPT), UAH 


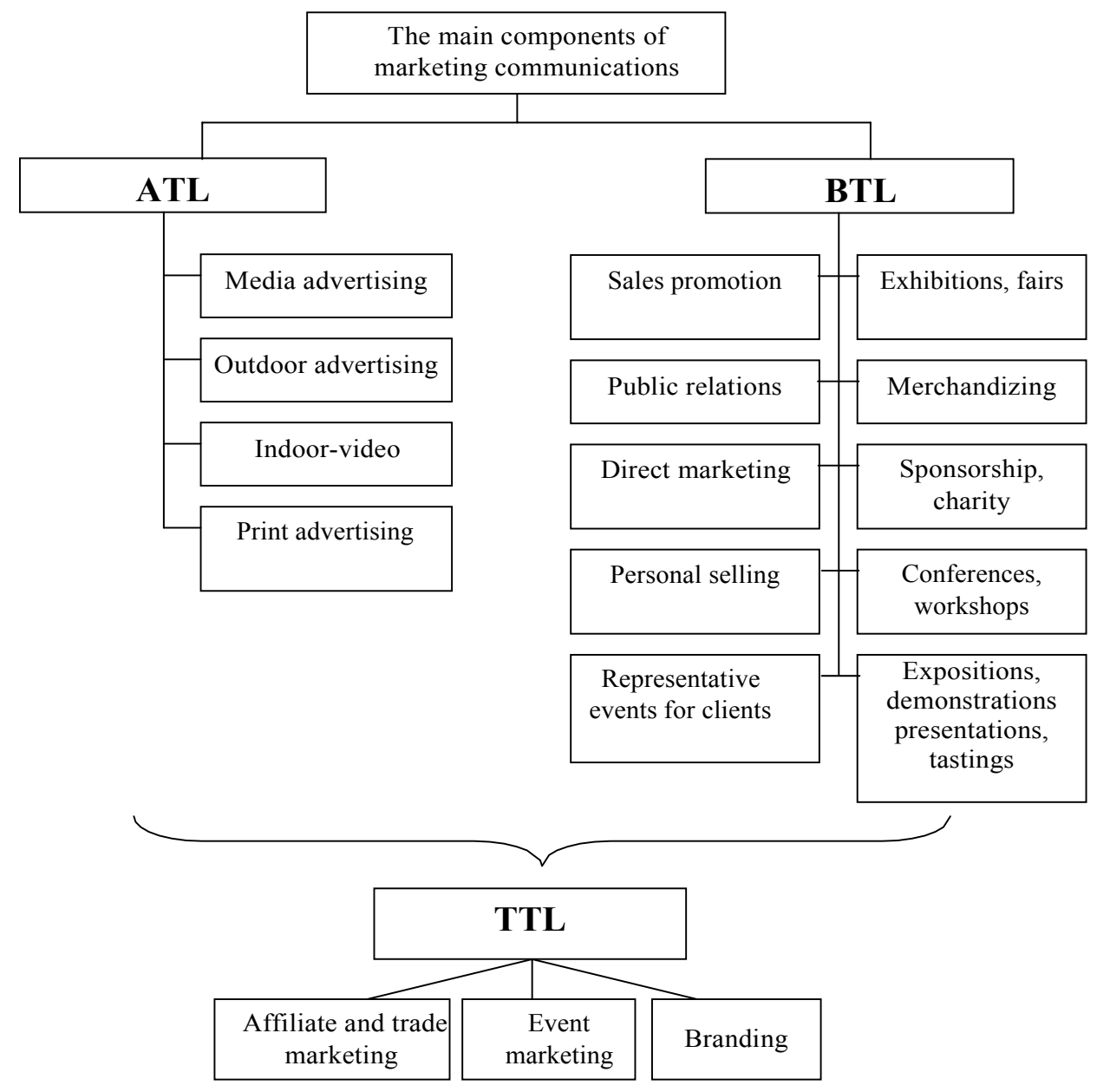

Figure 4. Distribution of tools of marketing communications by places of proactivity

stages of work are complemented with the classical algorithms that create the necessary preconditions for preventing or neutralizing the identified problems in the organization of Internet marketing communications. At the first stage, a conceptual model of communication is being developed that links internet marketing strategies with predictable user behavioural scenarios within the object-information model of a special program or project.

Thus, a basis for the full integration of Internet communication tools into marketing is created, interactivity and creative synthesis of methods and means of interaction with the audience, which does not deny the achievement of predicted economic results, are ensured. After all, with the development of the market, consumer needs, increased competition, an increase in the number of channels, communication devices, as well as the integration of offline and online sectors each problem of effective interaction, communication support for consumers becomes non-trivial.

The procedures for planning and organizing Internet marketing communications are not confined to an intuitive definition of the structure of tools and budgets used, as a percentage of revenue or profit, according to objectives and objectives (KPI), based on retrospective data, special studies (SOV), estimates of econometrics (ROI), etc., and become the stages of system harmonization of actions within the integral business model of the enterprise.

At present, in the processes of pricing, payment for information and communication intermediaries, there is virtually no clear ranking (Braslavskiy, 2003, Kubka, 2017, Berezin, 2014).

The effectiveness of the CPM model depends entirely on the derivative results of user behaviour (review of site materials, ordering and purchasing goods). Therefore, depending on the goals of the campaign - target audience expansion or sales promotion - the result may be more or less predictable, but not guaranteed.

For the first group of tasks, it is more acceptable to use CPC models; however, it also does not allow completely preventing artificial overestimation of attendance rates and others. The latter is ensured by the use of the CPL terms (Kubka, 2017; Smolyanyuk, 2013).

The CPL, CPA, and CPO models provide the prerequisites for the active and interactive participation of enterprises in communications and interaction with potential customers. Filling out an order form 
Table 4

Model for determining the levels of probability of communication and economic performance in collaboration with Internet market intermediaries

\begin{tabular}{|l|c|c|c|}
\hline \multicolumn{1}{|c|}{ Model } & \multicolumn{2}{|c|}{ Marketing result } & $\begin{array}{c}\text { Economic } \\
\text { efficiency }\end{array}$ \\
\cline { 2 - 4 } & Possible & $\begin{array}{c}\text { Fully or partly } \\
\text { guaranteed }\end{array}$ \\
\hline $\begin{array}{l}\text { CPM (Cost Per Mil) - fixed price/payment (PPI - Pay Per Impression) } \\
\text { for thousands of ad impressions, banner, or other media. }\end{array}$ & $\mathrm{X}$ & & \\
\hline $\begin{array}{l}\text { CPC (Cost Per Click) - price/payment (PPC - Pay Per Click) per click on the carrier } \\
\text { of marketing information. }\end{array}$ & $\mathrm{X}$ & $\mathrm{X}$ & \\
\hline $\begin{array}{l}\text { CPL (Cost Per Lead) - price/payment (PPL - Pay Per Lead) per lead (the fact that } \\
\text { the users perform a useful action, with the receipt of certain information about them). }\end{array}$ & $\mathrm{X}$ & $\mathrm{X}$ & \\
\hline $\begin{array}{l}\text { CPA (Cost Per Action) - price/payment (PPA - Pay Per Action) for a specific user } \\
\text { action (viewing a certain number of pages, participating in a poll, etc.). }\end{array}$ & $\mathrm{X}$ & $\mathrm{X}$ & $\mathrm{X}$ \\
\hline $\begin{array}{l}\text { CPO (Cost Per Order) - fixed payment subject to ordering by the visitor } \\
\text { on the advertiser's site. }\end{array}$ & & & $\mathrm{X}$ \\
\hline CPS (Cost Per Sale) - price/payment (PPS - Pay Per Sale) per sale. & & \\
\hline
\end{tabular}

or participating in special offers guarantee economic benefits of at least 50\%, nevertheless, the higher cost of service and the risk of losing potential customers through the establishment of rigid priority filters in the development of communications with the target audience make the CPA model more popular. Similarly, the price of productive communication with the guaranteed sale of goods/services is high and may amount to $10-30 \%$ of the sum of their order by the buyer (Emelyanov, 2002; Yerofeyev, 2016).

Accordingly, optimizing the parameters of communication programs and projects, taking into account the cost and effectiveness of placing marketing information on the network, leads to the choice of advertisers of CPA models in more than $70 \%$ of cases, CPS - about $50 \%$, and $25-35 \%$ of companies selects CPL. Other models have a mostly supporting or complementary role. Such a division, albeit with certain variations in the ranges, is peculiar for the USA, Europe, including its eastern part (Obzory rynkov, 2018). Complexity in using the models of organization of interaction and payment for partner services, providing banners, ads, thematic publications, and other elements of communication creates the preconditions for the effective management of communication efficiency.

It is logical to use CPM and CPC models in the early stages of the product lifecycle in the market, as well as for subject- or audience-specific recourses where it is important to provide certain awareness of the potential audience. In order to ensure the popularity and establishment of initial contact with potential consumers, the necessary condition is the active interest of the network's user, which makes fair the payment for the actions in the CPO, CPA, CPL models. They are also acceptable for the maintenance of retail offline sales of already known products, such as dairy products, professional services, etc., whose direct sale in the Internet environment is complicated (Yaroshenko, 2017).
In order to take into account the important aspects of each position, the transition between them, in implementing an integrated marketing communications program, in our view, it is advisable to propose appropriate taxonomic models that can increase the effectiveness of marketing communications on the Internet.

At this time, advertisers through stock exchanges (auctions) are purchasing information to certain audiences at sites (publishers and networks). At first glance, trade is based on accurate data, however, the situation of uncertainty and high risk remains. The main elements of the system that cause this are auctions and primary data. In the absence of efficient filters, instead of which the experience is often offered, in the form of corrected databases or behaviour patterns or manifestations of randomness, formalized in the algorithms, the latter introduce large errors in the plans.

Automation of the procedures for the operation of the advertising system provides the expenditure of funds, which marketers are ready to invest, by machines according to a specific algorithm. In most cases, optimization is carried out according to context, user profile, RFMP (Yaroshenko, 2017).

Thanks to the improvement of advertising purchase algorithms, it is possible to optimize the target audience based on the location, context of the requested information, RFM, etc. Taking into account sociodemographic parameters, consumer interests, etc. require creative approaches to segmentation using a large number of unique criteria. Such algorithms have already begun to be used by leading world companies such as Google and Yandex but the overall level of their use by domestic enterprises remains rather low.

In solving the above problems, it is possible to make some recommendations. The success of online platforms is based on the consistent development of activities, which is harmonized by three benchmarks: differentiation, effectiveness, efficiency. If earlier, 
marketing monitoring of the audience and behaviour of Internet users was mainly based on the features of its persons or contingents, as well as the information context, today it needs to be comprehensively integrated (contextual targeting, retargeting, and other tools).

Audience targeting, as a tool for improving the efficiency of an advertising campaign, can be carried out according to the criteria of geography, advertising areas, time and frequency of impressions, language parameter, age and gender of the user.

Continuous optimization of an advertising campaign by adjusting data from ad networks and combining multiple types of targeting ensures maximum effect from advertising. After reaching the Internet user, and the first signs of forming his/her loyalty as a consumer, it is expedient to use retargeting. Targeting allows enterprises to reduce the cost for attracting the target audience and, with proper use, gives the relevance of the information of advertisement messages to interested users in order to increase the loyalty to this type of message.

Thus, the optimality of the current message in marketing communications will be ensured by the interactivity and dynamism of content and structure based on formats, content, conditions, and audience. This becomes possible due to a single advertising platform that includes cross-channel attribution, a single profile for each user.

The control of the correctness of the target audience selection algorithms should be established on the basis of the identification of the limited sample of persons (n) among those involved in communications $(\mathrm{N})$, the scale of the error ( $q$ ). If $q \leq q_{m p}$, that is, below the permissible deviation level for a sample of a selected representation, then the operating mode remains unchanged. In such a situation, the risks of an advertiser $(\beta)$ who can pay messages to non-prospective network users are balanced with the risks of an intermediary $(\alpha)$ who may not be able to pay for the communications of potential customers (Emelyanov, 2002):

$$
\begin{aligned}
& \alpha=1-\sum_{d=0}^{c} \frac{C_{D_{0}}^{d} C_{N-D_{0}}^{n-d}}{C_{N}^{n}} \\
& \beta=\sum_{d=0}^{c} \frac{C_{D_{1}}^{d} C_{N-D_{1}}^{n-d}}{C_{N}^{n}}
\end{aligned}
$$

where $D_{0,1}, d$ - the number of mistakenly covered individuals in the Internet users' group checked for compliance with the selection criteria;

c - permissible error value for a given group of network participants involved in the communication.

$\mathrm{D}_{0,1}$ or $\mathrm{q}$ - random variables determined by the ratio $\mathrm{q}=\mathrm{D} / \mathrm{N}$.

In different situations, uncertainty in the work with the target audience, as well as the level of effectiveness of the intermediaries in the performance of their functions, it is possible to simplify or, conversely, increase control over the efficiency of communications. Similarly, activity is regulated using the probability $(\mathrm{P})$ of the appropriateness or inappropriateness of the local group of persons involved in communication with a certain share of random (unpromising) users of the network. This probability is determined by the expression under the sign of the sum in formulas 1 and 2 .

$$
\begin{aligned}
& \mathrm{P}\left(\mathrm{q}_{0}\right)=1-\alpha, \\
& \mathrm{P}\left(\mathrm{q}_{1}\right)=\beta .
\end{aligned}
$$

In the case of acceptability of simplified control procedures for the application of the hypergeometric distribution of random variables, it can be replaced by binomial. If $\mathrm{nq}$ is in the range of 0.1-20, then it is possible to use an even simpler Poisson distribution (Emelyanov, 2002):

$$
P(q)=\sum_{d=0}^{c} e^{-\lambda} \frac{\lambda^{d}}{d !}
$$

Using the formulas given above, it is possible to form different partnership options for communication systems that differ significantly in the choice of source data (Emelyanov, 2002). At the same time, the realization of real calculations is available to specialists with the usual level of training. So, if Internet resources provide coverage of 2250 users corresponding to the target audience with a concurrent error in the local control group $n=125$ (table values) at $1 \%$, then the number of random participants should not exceed 4, $\mathrm{P}=95 \%, \alpha=5 \%$. That is, every 100 of the periods, on average, 5 times the results of the work will be mistakenly rejected and, therefore, not paid. The advertiser is risking here five times to pay for work unreasonably, the results of which $-6.2 \%$ of random and commercially unpredictable participants of communication.

Accordingly, the second one of the problems declared at the beginning of the article finds its solution - the concentration of the majority of the enterprises on a narrow audience of consumers. So, online advertisers are mostly interested in young people aged 19-23. And here it is economically viable and relevant to see the application of new, more complex approaches to the choice of the target audience, its elemental and structural optimization.

\section{Conclusions}

The growth of the Internet users' audience is a steady and global trend, which is intensifying with the increase of means and options for access to the Internet, multimedia, and an increase in the time spent by consumers online. In the context of the growth of the Internet audience, as well as the media communications market as a whole, in Ukraine, the market for Internet marketing communications increases its capacity and improves, with some fluctuations of the indicators of the market conditions during the crisis periods. 
Among advertisers and representatives of different target audiences, commercials are gaining in popularity that not only and not so much provide (display) graphic, video or other information as interact with the user, turning him from observer to event participant, fully integrate the processes of active presentation of offers and persuasion in making purchasing decisions.

Internet marketing communications must be fully integrated into the cycle of interactive and renewable communication with consumers, whose results guarantee enterprises profitability and business development.

The volume of revenues from the creation and placement of advertising in 2017 amounted to 10003 million UAH.

The proactive elements used to provide interactivity (games, education, discussions, virtual demonstrations and excursions, etc.) are a guarantee of efficiency and must be combined with all the tools of the marketing communications package that is possible in the Internet environment.

In order to ensure the popularity and establish initial contact with potential consumers, the necessary condition is the active interest of the network's user, which makes fair the payment for the actions in the CPO, CPA, CPL models.

Thanks to the improvement of advertising purchase algorithms, it is possible to optimize the target audience based on the location, context of the requested information, RFM, etc. Taking into account sociodemographic parameters, consumer interests, etc. requires creative approaches to segmentation using a large number of unique criteria. Such algorithms have already begun to be used by leading world companies such as Google and Yandex, however, the overall level of their use by domestic enterprises remains rather low.

\section{References:}

Andropova, N. P. (2009). Marketynhovi komunikatsiyi v Interneti: navchalnyy posibnyk [Marketing Communication on the Internet: a tutorial]. Volgograd: WF RGTEU.

Berezin, D. (2014). Multikanalnaya personalizatsiya [Multichannel Personalization]. Retrieved from: http://www.slideshare.net/ADV_web_engineering/etarget-berezin-14-2

Bozhkova, V. V. (2013). Teoretychni pidkhody do klasyfikatsiyi instrumentiv marketynhovykh komunikatsiy [Theoretical Approaches to the Classification of Marketing Communication Tool]. Naukovyy visnyk Uzhhorodskoho universytetu. Seriya «Ekonomika», issue 2 (39-1), pp. 31-37.

Braslavskiy, P. I. (2003). Teatr i virtualnaya realnost: predposylki i perspektivy konvergentsii [Theater and virtual reality: preconditions and perspectives of convergence]. Retrieved from: http://zhurnal.ape.relarn.ru/ articles/2003/008.pdf.

Emelyanov, A. S. (2002). Ekonometriya i prohnozuvannya [Econometrics and forecasting]. Moscow: Economics. Gayeva,D.D.(2015).Internet-tekhnologiikakmarketingovyyinstrumentzarubezhnykhkompaniy[Internettechnologies as a marketing tool of foreign companies]. Retrieved from: www.econ.msu.ru/cmt2/lib/a/800/File/Gaeva.pdf.

Hendrik Pol (2015). Key role of cultural and creative industries in the economy. Retrieved from: http://www.oecd.org/ site/worldforum06/38703999.pdf

Internet: promyshlennost 4.0. [Internet: Industry 4.0.]. Retrieved from: https://www.deutschland.de/ru/topic/ ekonomika/innovaciitehnologii/internet-promyshlennost-40

Internet World Stats. Retrieved from: http://www.pingdom.com/

Industriya kompyuternykh igr obgonyayet kinoindustriyu [The computer games industry is ahead of the film industry]. Retrieved from: https:/ / www.deutschland.de/ru/topic/ekonomika/innovacii-tehnologii/pokolenie

Kashin, V. (2014). Data Driven Marketing. Retrieved from: http://2014.etarget.ru/ppt/2014/29-kashinetarget2014.pdf.

Khovi Dzheykobson. (2008). Google AdWords i kontekstnaya reklama dlya «chaynikov» [Google AdWords and contextual advertising for "Dummies"]. Moscow: Williams.

Kubka, M. (2017). Novyye instrumenty dlya raboty s konversiyami [New tools for working with conversions]. Retrieved from: http://www.slideshare.net/kmih/e-target-33033170

McLuhan, H. M. (2006). Ponimaniye media: Vneshniye rasshireniya cheloveka [Understanding media: external expansions of man]. Retrieved from: htlp://www.v.yanko.lib.iu/books media/mcluhan-understanding_media.pdf Mironova, D. A. (2016). Gazetnyy mediatekst onlayn-formata kak osobyy kommunikatsionnyy fenomen [Newspaper media text of the online format as a special communication phenomenon]. Retrieved from: http:/ cyberleninka.ru/article/n/gazetnyy-mediatekst-onlayn-formata-kak-osobyy-kommunikatsionnyy-fenomen

Nikiforova, E. (2017). Tekhnologii dlya realizatsii programm loyalnosti v yemeyl-soobshcheniyakh [Technologies for the implementation of loyalty programs in email messages]. Retrieved from: http://www.slideshare.net/ ellenikiforova/ss-32908923.

Obzory rynkov (2018). Informatsionno-analiticheskogo agentstva [Surveys of the markets of information and analytical agency]. Retrieved from: http://www.cbonds.info/ua/rus./

Ofitsiynyy sayt Ukrayinskoyi asotsiatsiyi Internet-reklamy (2018) [Official site of Ukrainian Association of Internet Advertising]. Retrieved from: http://www.inau.org.ua/analytics_vuq.phtml. 
Orap, A. (2016). Issledovaniye vospriyatiya brendov v sotsialnykh media. Prichiny, podkhody i primery [Research of brand perception in social media. Reasons, approaches and examples]. Retrieved from: http:/www.slideshare.net/ aorap/ss-9238053.

Petrovskiy, K. (2012). Optimizatsiya reklamnykh zatrat i pribylnosti sayta v tselom [Optimization of advertising costs and profitability of the site as a whole] Retrieved from: http://www.megaindex.tv/conference/eTarget_2012. Setevaya ekonomika [Network economy]. Retrieved from: http://ru.wikibooks.org/wiki/ \%D0\%A1\%D0\%B5\%D1\%82\%D0\%B5\%D0\%B2\%

Setevizatsiya mira [Networking the world]. Retrieved from: https://www.deutschland.de/ru/topic/ekonomika/ innovacii-tehnologii/setevizaciya

Smolyanyuk, O. V. (2013). Marketynhova skladova sotsialnykh merezh: svit ta Ukrayina [Marketing component of social networks: the world and Ukraine]. Ekonomika ta derzhava, no 8, pp. 112-117.

The Econimist Intelligence Unit. Retrieved from: http://country.eiu.com/Ukraine

Yaroshenko, A. (2017). Digital marketing management of Activia: a long-distance race. Retrieved from: http://www.slideshare.net/goldenalf/digital-marketing-management-of-activia-a-long

Yerofeyev, S. (2016). Targetirovannaya reklama: rabota nad oshibkami [Targeted advertising: work on mistakes]. Retrieved from: http://blogssmartzone.com/94185-.html

Zakon Mura [Moore's Law] Retrieved from: https://uk.wikipedia.org/wiki/\%D0\%97\%D0\%B0\%D0\%BA\%D0\% $\mathrm{BE} \% \mathrm{D} 0 \% \mathrm{BD} \%$ 